Morgana Michele Cavalcanti de Souza Leal Diniz',",

Alleksandra Dias da Silva
Henriques'

Renata da Silva Leandro'

Dalvanice Leal Aguiar'

Eduardo Barbosa Beserra'

Departamento de Biologia. Universidade Estadual da Paraíba. Campina Grande, PB, Brasil

Programa de Pós-Graduação em Saúde Pública. Faculdade de Saúde Pública. Universidade de São Paulo. São Paulo, SP, Brasil

Correspondence:

Morgana M. C. de S. L. Diniz

Rua Dr. Laerte Setubal, 610 apto. 704 Morumbi

05665-010 São Paulo, SP, Brasil

E-mail: morganac.diniz@gmail.com

Received: $11 / 21 / 2012$

Approved: 5/25/2014

Article available from: www.scielo.br/rsp

\section{Resistance of Aedes aegypti to temephos and adaptive disadvantages}

\section{Resistência de Aedes aegypti ao temefós e desvantagens adaptativas}

\begin{abstract}
OBJECTIVE: To evaluate the resistance of Aedes aegypti to temephos Fersol $1 \mathrm{G}$ (temephos $1 \% \mathrm{w} / \mathrm{w}$ ) associated with the adaptive disadvantage of insect populations in the absence of selection pressure.

METHODS: A diagnostic dose of $0.28 \mathrm{mg}$ a.i./L and doses between $0.28 \mathrm{mg}$ a.i./L and $1.40 \mathrm{mg}$ a.i./L were used. Vector populations collected between 2007 and 2008 in the city of Campina Grande, state of Paraíba, were evaluated. To evaluate competition in the absence of selection pressure, insect populations with initial frequencies of $20.0 \%, 40.0 \%, 60.0 \%$, and $80.0 \%$ resistant individuals were produced and subjected to the diagnostic dose for two months. Evaluation of the development of aquatic and adult stages allowed comparison of the life cycles in susceptible and resistant populations and construction of fertility life tables.
\end{abstract}

RESULTS: No mortality was observed in Ae. aegypti populations subjected to the diagnostic dose of $0.28 \mathrm{mg}$ a.i./L. The decreased mortality observed in populations containing $20.0 \%, 40.0 \%, 60.0 \%$, and $80.0 \%$ resistant insects indicates that temephos resistance is unstable in the absence of selection pressure. A comparison of the life cycles indicated differences in the duration and viability of the larval phase, but no differences were observed in embryo development, sex ratio, adult longevity, and number of eggs per female.

CONCLUSIONS: The fertility life table results indicated that some populations had reproductive disadvantages compared with the susceptible population in the absence of selection pressure, indicating the presence of a fitness cost in populations resistant to temephos.

DESCRIPTORS: Aedes, growth \& development. Temefos, toxicity. Insecticide Resistance. Insect Control. Dengue, prevention \& control. 


\section{RESUMO}

OBJETIVO: Avaliar a resistência de Aedes aegypti ao temefós Fersol 1G (temefós $1 \% \mathrm{p} / \mathrm{p}$ ) quanto à desvantagem adaptativa ao inseto, na ausência de pressão de seleção.

MÉTODOS: Foi aplicada a dose diagnóstica de $0,28 \mathrm{mg}$ i.a/L e concentrações entre $0,28 \mathrm{mg}$ i.a/L e $1,4 \mathrm{mg}$ i.a/L. Foram avaliadas amostras do vetor coletadas no município de Campina Grande entre 2007 e 2008, no estado da Paraíba. Para avaliar a competição na ausência de pressão de seleção, foram constituídos grupos de insetos com frequências iniciais de $20,0 \%, 40,0 \%, 60,0 \%$ e $80,0 \%$ de insetos resistentes, submetendo-os a dose diagnóstica por dois meses. Os ciclos de vida das populações suscetível e resistentes foram comparados avaliando-se as fases de desenvolvimento aquática e adulta, construindo-se tabelas de vida de fertilidade.

RESULTADOS: Não foram verificadas mortalidades nas populações de Ae. aegypti quando submetidas à dose diagnóstica de $0,28 \mathrm{mg}$ i.a./L. A diminuição da mortalidade nas populações com $20,0 \%, 40,0 \%, 60,0 \%$ e $80,0 \%$ de indivíduos resistentes indica que a resistência ao temefós é instável na ausência de pressão de seleção. A comparação do ciclo de vida mostrou diferenças na duração da fase e viabilidade larval, mas não quanto ao desenvolvimento embrionário, razão sexual, longevidade dos adultos e número de ovos/fêmea.

CONCLUSÕES: Pelos parâmetros da tabela de vida de fertilidade constatou-se que algumas populações apresentaram desvantagens reprodutivas em relação à população suscetível na ausência de pressão de seleção, havendo custo adaptativo resultante da resistência ao temefós.

DESCRITORES: Aedes, crescimento \& desenvolvimento. Temefós, toxicidade. Resistência a Inseticidas. Controle de Insetos. Dengue, prevenção \& controle.

\section{INTRODUCTION}

The prevention of dengue depends primarily on the decrease of vector populations in urban and periurban regions. ${ }^{8}$ However, Aedes aegypti's high degree of adaptation to urban environments hinders the control of its population density, increasing the prevalence of dengue throughout Brazil. ${ }^{12}$

In Brazil, control programs for Ae. aegypti primarily use chemical insecticides, with an emphasis on organophosphates and pyrethroids, which require constant monitoring. ${ }^{14}$ This control strategy faces numerous difficulties, the most important of which is mosquito resistance to the insecticides used (Tauil, ${ }^{21}$ 2002).

The resistance of Ae. aegypti to insecticides has been reported by numerous researchers in Brazil., 2,5,10,13,14,17 In the state of Ceará, Northeastern Brazil, resistant populations have been detected in the municipalities of Juazeiro do Norte, Crato, and Barbalha, as well as in neighborhoods in the capital Fortaleza (Lima et al, ${ }^{13}$ 2006). In Paraíba, Northeastern Brazil, resistance was diagnosed in insects collected in the municipalities of Boqueirão, Brejo dos Santos, Campina Grande, Itaporanga, Remígio, ${ }^{2}$ Alagoa Nova, Alagoa Grande, Serra Redonda, and Lagoa Seca. ${ }^{10}$

The detection of resistance and knowledge of the underlying resistance mechanisms can help to elucidate basic aspects of insecticide resistance and allow resistance management. ${ }^{4,19}$ In populations with a fitness cost resulting from insecticide resistance, instability can be exploited in resistance-management programs (Konno \& Omoto, ${ }^{11}$ 2006) because some of their main characteristics include adaptive disadvantage and loss of the biotic potential of resistant strains. Resistant populations are less fit than susceptible ones in the absence of selection pressure. This lower adaptive response of resistant populations may be associated with decreased overall viability and fertility, extended development time, decreased competitiveness for mating, and increased susceptibility to natural enemies. ${ }^{18}$

Considering that the evaluation of competition and fitness cost in resistant populations of Ae. aegypti 
can help guide resistance-management programs, the present study aimed to evaluate the resistance of Ae. aegypti to temephos Fersol $1 \mathrm{G}$ (temephos $1 \% \mathrm{w} / \mathrm{w}$ ) associated with the adaptive disadvantage of these populations in the absence of selection pressure.

\section{METHODS}

The study was conducted between August 2007 and July 2008. The laboratory bioassays and the rearing of Ae. aegypti were performed in the Laboratory of Entomology in the Center for Insect Bioecology and Systematics (Núcleo de Bioecologia e Sistemática) of the Universidade Estadual da Paraiba. Insects were maintained at $27.0^{\circ} \mathrm{C}$ [SE (standard error): 2.0], in a 12:12-h light-dark cycle, and the F1 generation of newly hatched eggs was collected in the neighborhoods of Catolé, Monte Santo, Nova Brasília, Liberdade, and Estação Velha, in the city of Campina Grande, PB, Northeastern Brazil. In these neighborhoods, traps for egg collection (ovitraps) were randomly distributed in 100 households and collected four days after installation. In the laboratory, this material was used to identify the species and establish the insect strains, following the methodology described by Beserra et $\mathrm{al}^{2}$ (2007) and Beserra \& Castro $\mathrm{Jr}^{3}$ (2008).

Resistance was assessed using the larvicide temephos Fersol 1G (temephos $1 \% \mathrm{w} / \mathrm{w}$ ). This product was initially diluted in water to obtain a stock solution of $100 \mathrm{mg}$ a.i./L and then diluted into the working concentrations. The diagnostic dose was determined using a multiple-concentration test and the diagnostic dose was considered to be twice the $\mathrm{LC}_{90}$ value for the susceptible population (S). Temephos resistance in field populations of Ae. aegypti was evaluated starting with the diagnostic dose measured in tests involving susceptible populations (S) and in the multipleconcentration test, where the dose varied between $0.28 \mathrm{mg}$ a.i./L and $1.4 \mathrm{mg}$ a.i./L.

For each test, 25 late-third-stage larvae (L3) and/or early fourth instar larvae (L4) were transferred to polyethylene beakers $(500 \mathrm{~mL})$ containing $250 \mathrm{~mL}$ of each insecticide solution diluted in distilled water, and this procedure was repeated four times. After larval exposure to the larvicide for $24 \mathrm{~h}$, the mortality rate was evaluated. Populations with a mortality rate of $98.0 \%$ were considered susceptible, those with a mortality rate between $80.0 \%$ and $98.0 \%$ were considered as requiring verification of resistance, and those with a mortality of $\leq 80.0 \%$ were considered resistant. Each bioassay was repeated three times on successive weeks.

Using a susceptible laboratory population (Rockefeller) and a temephos-resistant population from Catolé established in a previous bioassay, populations with $20.0 \%, 40.0 \%, 60.0 \%$, and $80.0 \%$ resistant insects were produced. For each established population, 100 larvae of Ae. aegypti were transferred to plastic trays using different ratios of susceptible and resistant larvae and reared until the pupal stage. The adults were maintained in screened cages $\left(20 \mathrm{~cm}^{3}\right)$ for mating to produce eggs for the susceptibility bioassays.

The susceptibility to temephos Fersol $1 \mathrm{G}$ was monitored for two months, starting with the diagnostic dose determined in tests involving the susceptible population, and in a multiple-concentration test where the dose varied between $0.14 \mathrm{mg}$ a.i./L and $1.96 \mathrm{mg}$ a.i./L. Mortality data for each population were subjected to Probit analysis using POLO-PC software for calculating the $\mathrm{LC}_{50}$ and $\mathrm{LC}_{90}$ values.

The life cycles of the susceptible and resistant populations were compared in 100 newly hatched larvae, which were maintained in groups of five per $250 \mathrm{~mL}$ polyethylene beaker in distilled water. The following parameters were measured daily: temperature and $\mathrm{pH}$ of the water used for larval and pupal development using a chemical thermometer with an upper temperature limit of $60^{\circ} \mathrm{C}$ and a digital $\mathrm{pH}$ meter, and humidity using a digital thermo-hygrometer model HT-210. The pupae were classified by sex and adults were maintained in wooden screened cages $\left(20 \mathrm{~cm}^{3}\right)$ using five cages per population, each cage containing 10 male and 10 female insects. Larvae and adults were fed according to a method used for rearing Ae. aegypti. The embryo phase was assessed on the eggs resulting from the first 10 ovipositions, which were transferred to Petri dishes $(9.0 \mathrm{~cm}$ diameter $\times 1.5$ $\mathrm{cm}$ deep) containing enough distilled water to cover the eggs. The embryo phase was evaluated daily and involved the recording of the development period and mortality rates of the egg, larval, and pupal phases as well as the sex ratio, longevity, and fecundity of the adult stage. The biological variables evaluated were subjected to variance analysis and the means were compared using the Tukey test $(\mathrm{p}<0.05)$ following a completely randomized design.

The biological variables analyzed allowed the construction of fertility life tables (Silveira-Neto et al, ${ }^{20}$ 1976). The age intervals $(x)$, specific fecundity $\left(m_{x}\right)$, and survival probability $\left(l_{x}\right)$ were also evaluated. The net reproductive rate $\left(R_{0}\right)$, mean generation time $(T)$, intrinsic rate of natural increase $\left(r_{m}\right)$, finite rate of increase $(\lambda)$, and population-doubling time (DT) were calculated, where: $\mathrm{R}_{0}=\Sigma\left(\mathrm{l}_{\mathrm{x}} \cdot \mathrm{m}_{\mathrm{x}}\right) ; \mathrm{T}=\Sigma\left(\mathrm{l}_{\mathrm{x}} \cdot \mathrm{m}_{\mathrm{x}} \cdot \mathrm{x}\right) / \Sigma\left(\mathrm{l}_{\mathrm{x}} \cdot \mathrm{m}_{\mathrm{x}}\right) ; \mathrm{r}_{\mathrm{m}}=\ln \left(\mathrm{R}_{0}\right) / \mathrm{T}$; $\lambda=$ erm; TD $=\ln (2) / \mathrm{r}_{\mathrm{m}}$

\section{RESULTS}

The tests conducted using the susceptible laboratory strain (Rockefeller) to determine the diagnostic dose to be applied to field populations yielded a $\mathrm{LC}_{90}$ of 
$0.14 \mathrm{mg}$ a.i./L. On the basis of this result, a diagnostic dose of $0.28 \mathrm{mg}$ a.i./L was obtained, which is twice the $\mathrm{LC}_{90}$ value for the susceptible strain.

All the populations collected in the districts of Catolé, Monte Santo, Nova Brasília, Liberdade, and Estação Velha showed no mortality when subjected to multiple insecticide concentrations varying between $0.28 \mathrm{mg}$ a.i./L and $1.4 \mathrm{mg}$ a.i./L. The absence of mortality in these populations hindered the calculation of $\mathrm{LC}_{50}$ and $\mathrm{LC}_{90}$, and consequently their resistance ratios. Considering that all populations were resistant, the Catolé population was randomly selected to investigate competition in the absence of selection pressure between Ae. aegypti populations that were susceptible and resistant to temephos.

Ae. aegypti populations with distinct ratios of resistant individuals in the absence of selection pressure showed different mortality rates when subjected to the diagnostic dose of $0.28 \mathrm{mg}$ a.i./L. Higher mortality rates were observed for the populations containing $20.0 \%$ and $40.0 \%$ resistant individuals, and mortality rates decreased from June $(91.0 \%$ and $59.0 \%$, respectively) to July (78.0\% and $31.0 \%$, respectively) in these populations. Populations with $60.0 \%$ and $80.0 \%$ resistant individuals had the lowest mortality rates in June (12.0\% and $42.0 \%$, respectively) and July (6.0\% and $0 \%$, respectively).

The $\mathrm{LC}_{50}$ and $\mathrm{LC}_{90}$ values followed the increase in the number of resistant individuals in each population. These values increased from $0.073 \mathrm{mg}$ a.i./L and $0.225 \mathrm{mg}$ a.i./L, respectively, in the group with $20.0 \%$ resistant insects, to $1.627 \mathrm{mg}$ a.i./L and $2.227 \mathrm{mg}$ a.i./L, respectively, in the group with $80.0 \%$ resistant individuals (Table 1 ).

The mean temperature of the water where larval development occurred was $26.4^{\circ} \mathrm{C}$ for the susceptible Rockefeller and Catolé populations; $26.5^{\circ} \mathrm{C}$ for the populations collected in Monte Santo, Nova Brasília, and Estação Velha; and $26.7^{\circ} \mathrm{C}$ for the population collected in Liberdade (Table 2). The mean room temperature was $27.0^{\circ} \mathrm{C}\left(\mathrm{SE}: 2.0^{\circ} \mathrm{C}\right)$ and the $\mathrm{pH}$ ranged from 5.8 to 6.1 .
No significant differences were observed with respect to embryonic development period among the populations evaluated; this period ranged between 2.1 and 2.9 days (Table 3 ). However, significant differences were observed in egg viability: viability was lower $(33.5 \%)$ in the susceptible population and higher $(91.3 \%)$ in the Monte Santo population (Table 3). Significant differences were observed in the duration of larval development and larval viability, but not in the sex ratio (Table 3). The longest development period (9.0 days) and lowest larval viability (36.0\%) were found in the population collected in Estação Velha. These variables were not significantly different in the remaining resistant populations (Table 3 ). The number of eggs per female did not significantly differ among the populations evaluated, and no significant variation was seen in adult longevity, which ranged between 26.5 and 37.7 days for male adults and between 23.8 and 37.9 days for female adults (Table 4).

The net reproductive rate $\left(\mathrm{R}_{0}\right)$, mean generation time $(T)$, innate capacity for increase in numbers $\left(r_{m}\right)$, finite rate of increase $(\lambda)$, and DT for the susceptible population were $130.78,4.11,1.12,3.06$, and 0.61 , respectively. The Ae. aegypti population from Estação Velha showed the highest $\mathrm{R}_{0}(152.58)$ and $\mathrm{r}_{\mathrm{m}}(1.14)$, the population from Liberdade showed the highest $\lambda$ (3.18), and the population from Monte Santo had the largest $\mathrm{T}$ (5.12) and DT (0.83) (Table 5).

\section{DISCUSSION}

The occurrence of temephos resistance in all Ae. aegypti populations evaluated corroborates what has been observed in other Brazilian cities ${ }^{5,13,14,17}$ and in Paraíba, 2,10 where resistance to this insecticide evolved rapidly in most studied populations. For example, of seven $A e$. aegypti populations collected in Brasília (DF), Midwest Brazil, and evaluated by Carvalho et $\mathrm{al}^{7}$ (2004), three showed insecticide resistance, with mortality rates varying between $54.1 \%$ and $63.4 \%$ in the first year, and all population groups were resistant in the second year, with mortality rates between $44.4 \%$ and $66.4 \%$. In Foz do Iguaçu, in the state of Paraná, Southern Brazil, low

Table 1. Concentration-mortality response in Aedes aegypti populations with different proportions of individuals susceptible and resistant to temephos Fersol 1 G (temephos 1\% w/w). Campina Grande, PB, Northeastern Brazil, 2007-2008.

\begin{tabular}{lcccccccc}
\hline $\begin{array}{l}\text { Percentage of } \\
\text { resistant individuals } \\
\text { in the population }\end{array}$ & $\begin{array}{c}\mathrm{LC}_{50} \\
(\mathrm{mg} \text { a.i./L) }\end{array}$ & $95 \% \mathrm{Cl}$ & $\begin{array}{c}\mathrm{LC}_{90} \\
(\mathrm{mg} \text { a.i./L) }\end{array}$ & $95 \% \mathrm{Cl}$ & $\mathrm{b}$ & $\mathrm{SE}$ & $\mathrm{X}^{2}$ & d.f. \\
\hline 20.0 & 0.073 & $0.041 ; 0.100$ & 0.225 & $0.194 ; 0.259$ & 2.639 & 0.44 & 21.27 & 22 \\
40.0 & 0.275 & $0.255 ; 0.295$ & 0.636 & $0.556 ; 0.767$ & 3.519 & 0.32 & 16.40 & 22 \\
60.0 & 0.579 & $0.518 ; 0.632$ & 1.303 & $1.165 ; 1.516$ & 3.637 & 0.35 & 13.07 & 18 \\
80.0 & 1.627 & $1.585 ; 1.671$ & 2.227 & $2.103 ; 2.420$ & 9.407 & 0.95 & 8.06 & 22 \\
\hline
\end{tabular}

$\mathrm{LC}_{50}$ : lethal concentration to $50 \%$ organisms exposed; $\mathrm{LC}_{90}$ : lethal concentration to $90 \%$ organisms exposed; b: linear slope; SE: standard error; $X^{2}$ : Chi-square test; d.f.: degrees of freedom 
Table 2. Temperature and $\mathrm{pH}$ of the water during larval development of Aedes aegypti populations. Campina Grande, PB, Northeastern Brazil, 2007-2008.

\begin{tabular}{lcl}
\hline Population & Temperature $\left({ }^{\circ} \mathrm{C}\right)$ & $\mathrm{pH}$ \\
\hline Rockefeller & 26.4 & 6.0 \\
Catolé & 26.4 & 6.1 \\
Estação Velha & 26.5 & 5.8 \\
Liberdade & 26.7 & 5.8 \\
Monte Santo & 26.5 & 6.0 \\
Nova Brasília & 26.5 & 5.9 \\
\hline
\end{tabular}

levels of temephos resistance were observed for both Ae. aegypti and Ae. albopictus populations. ${ }^{10}$

In this study, it was not possible to determine resistance ratios for the samples evaluated. However, considering the absence of mortality among individuals exposed to multiple temephos concentrations, it can be inferred that the resistance levels were high, and similar results were observed in Ae. aegypti populations in other cities in Paraíba. ${ }^{2,10}$ Beserra et al ${ }^{2}$ (2007) showed that the levels of temephos resistance ranged from low to high in populations from Campina Grande, Brejo dos Santos, Boqueirão, Itaporanga, and Remígio. Gambarra et a ${ }^{10}(2013)$ showed that Ae. aegypti populations in Alagoa Nova, Alagoa Grande, Lagoa Seca, and Serra Redonda had high levels of resistance, supporting the hypothesis that temephos resistance is prevalent in several regions of the state.

The high levels of resistance of Ae. aegypti populations in Paraíba may be associated with the use of temephos at different intensities and frequencies of application, subjecting these groups to different selection pressures and resistance mechanisms, with a consequent increase in resistance. ${ }^{10}$
It is essential to elucidate the basic aspects of insect resistance to insecticides because this information can guide resistance-management programs for target species. ${ }^{19}$ In competition tests in the absence of selection pressure, mortality rates decreased with increasing frequencies of resistant individuals, and this result was similar to that observed for Sitophilus zeamais after exposure to deltamethrin. ${ }^{16}$

In general, the decreased survival rate among populations with different resistance ratios indicates that insecticide resistance is unstable in the absence of selection pressure. ${ }^{11}$ However, although a high mortality rate $(91.0 \%)$ was observed in the population with $20.0 \%$ resistant individuals, this rate tended to decrease in the subsequent month, and this was also observed in populations with $40.0 \%, 60.0 \%$, and $80.0 \%$ resistant individuals. Therefore, it can be inferred that, for the Ae. aegypti population collected in Catolé, resistance remains stable in the absence of selection pressure. This is an important aspect from the standpoint of resistance management because the maintenance of stable resistance prevents its reversal and consequently the restoration of susceptibility over time.

These results differ from those observed in populations of Chrysoperla externa resistant to Karate ${ }^{15}$ and Aphis gossypii resistant to carbosulfan, ${ }^{11}$ in which the survival rate significantly decreased in the absence of selection pressure, ${ }^{11}$ indicating the tendency for resistance to those insecticides to reverse.

The results of probit regression analysis indicated that the response to temephos differed between populations with different resistance ratios, i.e., the intensity and quality of the responses associated with insecticide resistance different in these groups. This is seen in the similarity tests and parallelism of the regression lines that rejected the hypothesis that the differences between

Table 3. Duration and viability of embryonic and larval development as well as the sex ratio of Aedes aegypti populations. Campina Grande, PB, Northeastern Brazil, 2007-2008.

\begin{tabular}{|c|c|c|c|c|c|}
\hline \multirow{2}{*}{$\begin{array}{l}\text { Variable } \\
\text { Populations }\end{array}$} & \multicolumn{2}{|c|}{ Eggs } & \multicolumn{2}{|l|}{ Larvae } & \multirow{2}{*}{ Sex ratio ${ }^{a}$} \\
\hline & Duration $\left(\right.$ days) $^{\mathrm{a}}$ & Viability $(\%)^{b, c}$ & Survival time of larvae & Viability $(\%)^{a, b}$ & \\
\hline Rockefeller (susceptible) & $2.1(0.5)^{\mathrm{ns}}$ & $33.5(12.9)^{b}$ & $7.2(0.2)^{b}$ & $72(9.6)^{\mathrm{a}}$ & $0.66(0.10)^{\mathrm{ns}}$ \\
\hline Catolé & $2.8(0.4)^{\mathrm{ns}}$ & $71.7(7.1)^{a . b}$ & $8.4(0.1)^{a . b}$ & $84(5.1)^{\mathrm{a}}$ & $0.40(0.0)^{\mathrm{ns}}$ \\
\hline Estação Velha & $2.9(0.3)^{\mathrm{ns}}$ & $75.7(10.4)^{a . b}$ & $9.0(0.3)^{\mathrm{a}}$ & $36(11.9)^{b}$ & $0.66(0.06)^{\mathrm{ns}}$ \\
\hline Liberdade & $2.4(0.3)^{\mathrm{ns}}$ & $64.7(9.4)^{a . b}$ & $7.3(0.2)^{b}$ & $82(6.6)^{\mathrm{a}}$ & $0.60(0.0)^{\mathrm{ns}}$ \\
\hline Monte Santo & $2.9(0.1)^{\mathrm{ns}}$ & $91.3(5.6)^{\mathrm{a}}$ & $8.2(0.3)^{a . b}$ & $86(5.1)^{\mathrm{a}}$ & $0.60(0.02)^{\mathrm{ns}}$ \\
\hline Nova Brasília & $2.7(0.3)^{\mathrm{ns}}$ & $40.1(10.2)^{b}$ & $7.3(0.3)^{b}$ & $72(7.3)^{\mathrm{a}}$ & $0.44(0.07)^{\mathrm{ns}}$ \\
\hline C.V. $(\%)$ & 20.9 & 31.8 & 8.6 & 18.7 & 39.2 \\
\hline
\end{tabular}

Note: Room temperature of $26^{\circ} \mathrm{C}$ (SE 2.0) and 12:12-h light-dark cycle.

C.V.: coefficient of variation

a Means and standard error. For purposes of statistical analysis, the data were transformed into $\sqrt{X}$

${ }^{\mathrm{b}}$ Means and standard error. For purposes of statistical analysis, the data were transformed into $\log (x+1.0)$.

c Means followed by the same letter in columns do not differ using Tukey's test $(p<0.01)$.

${ }^{n s}$ Not significant using the $\mathrm{F}$ test $(\mathrm{p}<0.05)$. 
Table 4. Adult longevity (days) and number of eggs per female among populations of Aedes aegypti. Campina Grande, PB, Northeastern Brazil, 2007-2008.

\begin{tabular}{lccc}
\hline \multirow{2}{*}{ Aedes aegypti populations } & \multicolumn{2}{c}{ Longevity $^{\mathrm{a}}$} & Fecundity $^{\mathrm{b}}$ \\
\cline { 2 - 3 } Rockefeller (susceptible) & Female & Male & $233.6(99.9)^{\mathrm{ns}}$ \\
Catolé & $34.3(7.9)^{\mathrm{ns}}$ & $31.8(8.1)^{\mathrm{ns}}$ & $113.9(30.8)^{\mathrm{ns}}$ \\
Estação Velha & $23.8(2.4)^{\mathrm{ns}}$ & $26.5(2.4)^{\mathrm{ns}}$ & $251.1(40.4)^{\mathrm{ns}}$ \\
Liberdade & $37.1(10.4)^{\mathrm{ns}}$ & $29.5(4.3)^{\mathrm{ns}}$ & $166.9(10.2)^{\mathrm{ns}}$ \\
Monte Santo & $37.9(3.8)^{\mathrm{ns}}$ & $37.7(1.6)^{\mathrm{ns}}$ & $243.8(36.6)^{\mathrm{ns}}$ \\
Nova Brasília & $30.8(2.0)^{\mathrm{ns}}$ & $35.2(3.3)^{\mathrm{ns}}$ & $88.5(24.7)^{\mathrm{ns}}$ \\
C.V. $(\%)$ & $24.7(2.5)^{\mathrm{ns}}$ & $29.3(2.1)^{\mathrm{ns}}$ & 17.8 \\
\hline
\end{tabular}

Note: Room temperature of $26^{\circ} \mathrm{C}(\mathrm{SE} 2.0)$ and 12:12-h light-dark cycle.

C.V.: Coefficient of variation

$a, b$ Original means and standard error. For the purpose of statistical analysis, the data were transformed into $\sqrt{X+0,5}$ and

$\log (x+1.0)$, respectively.

${ }^{\text {ns }}$ Not significant using the $\mathrm{F}$ test $(\mathrm{p}<0.05)$.

the slopes and intercepts are the same for these populations. This result is corroborated when the nonoverlapping confidence intervals of the $\mathrm{LC}_{50}$ and $\mathrm{LC}_{90}$ values are compared (Table 1).

Certain factors can restore insecticide susceptibility in resistant populations during resistance management. One of these factors is the fitness cost, since the evolution of resistance is usually associated with loss of biotic potential in the population. ${ }^{16,18}$ The period of embryonic development (Table 3 ) was considered short (ranging between 2.1 and 2.9 days on average) compared with the average development period observed by other authors in Ae. aegypti populations from Paraíba ${ }^{1,3}$ (between 3.8 to 6.1 days).

The longer development period and decreased larval viability found in the population collected in Estação Velha indicate a higher fitness cost in this population resulting from the development of resistance when compared with the fitness cost in the susceptible strain and the other resistant populations. In this case, at least for this population, it can be inferred that the fitness cost associated with resistance can be related to the parameters of larval development, and confers adaptive disadvantage for this vector population. However, regardless of population susceptibility or resistance, the results shown herein differ with those obtained by other authors. Beserra et $\mathrm{al}^{1}$ (2006) investigated a population of Ae. aegypti from Campina Grande and observed that the average period of larval development and larval viability were 6.6 days and $92.5 \%$, respectively. Similarly, the study by Beserra \& Castro $\mathrm{Jr}^{2}$ (2007) with Ae. aegypti in Boqueirão, Brejo dos Santos, Itaporanga, and Remígio showed an average larval development between 6.3 and 8.3 days and larval viability of $92.0 \%$.

Despite the disadvantage in the development parameters of the population from Estação Velha compared with the susceptible strain, these variables were not significantly different in the other resistant populations, corroborating the results of previous studies involving carbosulfam-resistant populations of Aphis gossypii. ${ }^{11}$ The duration of nymph development and nymph viability did not significantly differ from those of the susceptible strain. ${ }^{11}$ Similarly, no significant differences were observed in the duration of developmental stages in resistant and susceptible populations of Brevipalpus phoenicis. ${ }^{9}$

Table 5. Fertility life table of Aedes aegypti populations. Campina Grande, PB, Northeastern Brazil, 2007-2008.

\begin{tabular}{lccccc}
\hline Aedes aegypti populations & $\mathrm{R}_{0}$ & $\mathrm{~T}$ (weeks) & $\mathrm{r}_{\mathrm{m}}$ & $\lambda$ & $\mathrm{DT}$ (weeks) \\
\hline Rockfeller (susceptible) & 130.78 & 4.11 & 1.12 & 3.06 & 0.61 \\
Catolé & 44.22 & 4.50 & 0.84 & 2.31 & 0.82 \\
Estação Velha & 152.58 & 4.39 & 1.14 & 3.09 & 0.60 \\
Liberdade & 101.43 & 3.97 & 1.16 & 3.18 & 0.59 \\
Monte Santo & 71.69 & 5.12 & 0.83 & 2.29 & 0.83 \\
Nova Brasília & 35.53 & 4.10 & 0.87 & 2.34 & 0.79 \\
\hline
\end{tabular}

Note: Room temperature of $26^{\circ} \mathrm{C}$ (SE 2.0) and 12:12-h light-dark cycle.

$R_{0}$ : net reproductive rate; $T$ : average generation time; $r_{m}$ : innate capacity for increase in numbers; $\lambda$ : finite rate of increase;

DT: population-doubling time 
Adult longevity and the number of eggs per female did not differ between these populations. However, in all cases evaluated, the longevity of male adults (26.537.7 days) and female adults (23.8-37.9 days) (Table 4) was lower than that reported by Beserra \& Castro $\mathrm{Jr}^{3}$ (2008), who observed a mean variation between 42.1 and 46.1 days for female adults and between 42.8 and 44.5 days for male adults of Ae. aegypti collected in Brejo dos Santos, Boqueirão, Itaporanga, and Remígio. Although no significant differences were observed between the resistant and susceptible populations with regard to the number of eggs per female, lower average values were found for the populations in Catolé (113.9 eggs/female) and Nova Brasília (88.5 eggs/female) than for those obtained in the Rockefeller population (233.6 eggs/female). This may indicate that the resistance in these populations can confer reproductive disadvantages compared with the susceptible population in the absence of selection pressure. However, these results differ from those reported for resistant and susceptible populations of Brevipalpus phoenicis, which showed no significant differences in the fecundity and longevity of female adults. ${ }^{6,9}$

According to Table 2, water temperatures and $\mathrm{pH}$ during vector development showed little variation and these variables did not vary significantly to account for the biological differences observed between the samples evaluated. According to Beserra \& Castro $\mathrm{Jr}^{3}$ (2008), under these conditions, the observed biological differences result from the innate characteristics of each population.

\section{REFERENCES}

1. Beserra EB, Castro Jr FP, Santos JW, Santos TS, Fernandes CRM. Biologia e exigências térmicas de Aedes aegypti (L.) (Diptera: Culicidae) provenientes de quatro regiões bioclimáticas da Paraíba. Neotrop Entomol. 2006;35(6):853-60. DOI:10.1590/S1519-566X2006000600021

2. Beserra EB, Fernandes CRM, Queiroga MFC, Castro Jr FP. Resistência de Aedes aegypti (L.) (Diptera: Culicidae) ao organofosforado temefós na Paraíba. Neotrop Entomol. 2007;36(2):303-7. DOI:10.1590/S1519-566X2007000200019

3. Beserra EB, Castro Jr FP. Biologia Comparada de Populações de Aedes (Stegomyia) aegypti (L.) (Diptera: Culicidae) da Paraíba. Neotrop Entomol. 2008;37(1):81-5. DOI:10.1590/S1519-566X2008000100012

4. Braga IA, Valle D. Aedes aegypti: histórico de controle no Brasil. Epidemiol Serv Saude. 2007;16(2):113-8.
The fertility life tables confirmed that the Ae. aegypti populations collected in Catolé, Monte Santo, and Nova Brasília, unlike the population from Estação Velha, showed a reproductive disadvantage compared with the susceptible strain in the absence of selection pressure (Table 5). In addition, the net reproductive rate $\left(\mathrm{R}_{0}\right)$ was 130.78 for the susceptible population, in contrast with 44.22, 71.69, and 35.53 for the resistant populations of Catolé, Monte Santo, and Nova Brasília, respectively. This demonstrates the increased reproductive potential of the susceptible population compared with the resistant groups. Although increased $\mathrm{R}_{0}$ was observed in the susceptible population compared with that obtained in the Liberdade population $\left(\mathrm{R}_{0}=101.43\right)$, this difference can be compensated when considering $T, r_{m}, \lambda$, and DT, which corresponded to $3.97,1.16,3.18$, and 0.59 respectively, and were superior to those observed in the Rockefeller strain (Table 5).

The $r_{m}$ parameter, which corresponds to the optimal range of insect development, the number of times that a population multiplies per time unit, and the time required for the population to double in number, indicates that the development potential of resistant populations is lower than that of the susceptible population. Therefore, a fitness cost resulting from the resistance to temephos is harmful to the biotic potential of these populations.

\section{ACKNOWLEDGMENTS}

We are grateful to the $3^{\text {rd }}$ Regional Health Center of the Department of Health of Paraíba for their support and provision of material for performing the endurance test.

5. Campos J, Andrade CFS. Susceptibilidade larval de duas populações de Aedes aegypti a inseticidas químicos. Rev Saude Publica. 2001;35(3):232-6. DOI:10.1590/S0034-89102001000300003

6. Campos FJ, Omoto C. Estabilidade da resistência de Brevipalpus phoenicis (Geijskes) (Acari: Tenuipalpidae) a hexythiazox em pomares de citros. Neotrop Entomol. 2006;35(6):840-8. DOI: 10.1590/S1519-566X2006000600019

7. Carvalho MSL, Caldas ED, Degallier N, Vilarinhos PTR, Souza LCKR, Yoshizawa MAC, et al. Suscetibilidade de larvas de Aedes aegypti ao inseticida temefós no Distrito Federal. Rev Saude Publica. 2004;38(5):623-9. DOI:10.1590/S0034-89102004000500002

8. Corrêa PRL, França E, Bogutchi TF. Infestação pelo Aedes aegypti e ocorrência da dengue em Belo Horizonte, Minas Gerais. Rev Saude Publica. 2005;39(1):33-40. DOI:10.1590/S0034-89102005000100005 
9. Franco CR, Casarin NFB, Domingues FA, Omoto C. Resistência de Brevipalpus phoenicis (Geijskes) (Acari: Tenuipalpidae) a acaricidas inibidores da respiração celular em citros: resistência cruzada e custo adaptativo. Neotrop Entomol. 2007;36(4):565-76. DOI:10.1590/S1519-566X2007000400015

10. Gambarra WPT, Martins WFS, Lucena Filho MLL, Albuquerque IMC, Apolinário OKS, Beserra EB. Spatial distribution and sterase activity in populations of Aedes (Stegomyia) aegypti (Linnaeus) (Diptera: Culicidae) resistant to temephos. Rev Soc Bra Med Trop. 2013;46(2):178-84. DOI:10.1590/0037-8682-1727-2013

11. Konno RH, Omoto C. Custo adaptativo associado à resistência de Aphis gossypi Glover (Hemiptera: Aphididae) ao inseticida carbosulfam. Neotrop Entomol. 2006;35(2):246-50. DOI:10.1590/S1519-566X2006000200014

12. Kubota RL, Brito M, Voltolini JC. Método de varredura para exame de criadouros de vetores de dengue e febre amarela urbana. Rev Saude Publica. 2003;37(2):263-5. DOI:10.1590/S0034-89102003000200017

13. Lima EP, Oliveira Filho AM, Lima JWO, Ramos Jr AN, Cavalcanti LPG, Pontes RJS. Resistência do Aedes aegypti ao temefós em Municípios do Estado do Ceará. Rev Soc Bras Med Trop. 2006;39(3):259-63. DOI:10.1590/S0037-86822006000300006

14. Luna JED, Martins MF, Anjos AF, Kuwabara EF, Navarro-Silva MA. Susceptibility of Aedes aegypti to temephos and cypermethrin insecticides, Brazil. Rev Saude Publica. 2004;38(6):833-4. DOI:10.1590/S0034-89102004000600013
15. Oliveira JEM, Bartoli AS, Ferreira RJ, Mirandea JE. Suscetibilidade de Chrysoperla externa (Hagen) (Neuroptera: Chrysopidae) a Karate ${ }^{\circledast}$ Lambdacialotrina) em condições de laboratório. Bol Sanid Veg. 2002;28(4):577-84.

16. Oliveira EE, Guedes RNC, Corrêa AS, Damasceno BL, Santos CT. Resistência vs susceptibilidade a piretróides em Sitophilus zeamais Motschulsky (Coleoptera: Curculionidae): há vencedor? Neotrop Entomol. 2005;34(6):981-90. DOI:10.1590/S1519-566X2005000600015

17. Prophiro JS, Silva OS, Luna JED, Piccoli CF, Kanis LA, Silva MAN. Aedes aegypti and Aedes albopictus (Diptera: Culicidae): coexistence and susceptibility to temephos, in municipalites with occurrence of dengue and differentiated characteristics of urbanization. Rev Bras Med Tropical. 2011;44(3):300-5. DOI:10.1590/S0037-86822011005000025

18. Roush RT, Mackenzie JA. Ecological genetics of insecticide and acaricide resistance. Ann Rev Entomol. 1987;32:361-80. DOI:10.1146/annurev.en.32.010187.002045

19. Scott JA. The molecular genetics of resistance: resistance as a response to stress. Flor Entomol. 1995;78(3):399-414. DOI:10.2307/3495526

20. Silveira Neto S, Nakano O, Bardin D, Villa Nova NA. Manual de ecologia dos insetos. São Paulo: Agronômica Ceres; 1976.

21. Tauil PL. Aspectos críticos do controle do dengue no Brasil. Cad Saude Publica. 2002;18(3):867-71. DOI:10.1590/S0102-311X2002000300035

This research was supported by the Conselho Nacional de Desenvolvimento Científico e Tecnológico (CNPq) through a scholarship for Leal MMCS.

The authors declare no conflict of interest. 